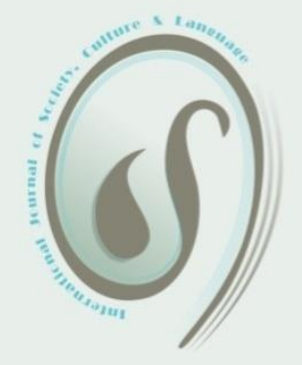

\title{
Bourdieu and Genette in Paratext: How Sociology Counts in Linguistic Reasoning
}

\author{
Hisham M. Ali ${ }^{1 \mathbf{a}}$
}

\section{ARTICLE HISTORY:}

Received April 2018

Received in revised form June 2018

Accepted July 2018

Available online July 2018

\section{KEYWORDS:}

Bourdieu

Genette

Gibran

Paratext

Translation

\begin{abstract}
While Bourdieu's theory of practice provides an ensemble of conceptual tools which analyze patterns of social life that are irreducible to the limiting view of individuals as freeacting agents, Genette's paratextual theory offers the metalanguage necessary to account for the microcosm of paratext as a linguistic space. This study takes issue with unidirectional approaches to researching paratexts in terms of linguistic or sociological accounts, and argues for a bidirectional understanding of paratext to unearth the interplay between structure and agency. Drawing on Genette's paratextual features and Bourdieu's sociology, this interactive approach is explored in a series of analyses of paratexts enveloping two Arabic translations of Gibran's The Earth Gods. Through a discussion of the linguistic manifestations and the socio-historical backdrops of paratexts, the paper argues that the preface with its attendant micro features has the potential to exhibit the translation illusio which epistemologically foregrounds the stakes and investments that motivate the production of translation.
\end{abstract}

\footnotetext{
${ }^{1}$ MA, Email: hisali@hbku.edu.qa Tel: +974-33-410552

${ }^{a}$ Hamad Bin Khalifa University, Qatar
} 


\section{Introduction}

ranslation history sources show the $\mathrm{T}$ dominance of process-oriented theories since as early as the first century BCE when Cicero (1949) described his sense-for-sense translation method as orator-oriented rather than interpreteroriented. The sweeping obsession with fluency and idiomaticity perpetuated a disregard for paratexts as potential sites of self-reflexivity where the dualism of structure and agency can be reconciled. This research examines the underlying sociological and linguistic parameters of paratexts in relation to the early Arabic translations of Gibran's poetry, with a particular focus on The Earth Gods and its first published translation (1932) by the Archimandrite Anthony Bashir and a further one (1965) by the late Egyptian Minister of Culture Tharwat Okasha. The study is premised on an understanding of paratexts as sociocultural products which typify the social trajectories of translators and their subjectivity in seeking to cater for the needs of their real or hypothetical target readers. It follows that I will utilize various theoretical tools from Bourdieu's conceptual canon.

Bourdieu's reflexive sociology in general, and genetic structuralism in particular, has marked a significant contribution not only to social theory and cultural studies but also to Translation Studies. In genetic sociology, Bourdieu considers the analysis of objective structures to be "inseparable from the analysis of genesis, within biological individuals, of mental structures which are to some extent the product of the incorporation of social structures" (1990, p. 14). For him, sociocultural practices converge at what he describes as "history in things" and "history in bodies" (1993, p. 46). Or to put this in Hanna's terms, the former signals "the history inscribed in institutional practices, social, economic and political structures", whereas the latter points to "the history hidden in people's heads and which disposes them to specific physical and intellectual behavior" (2005, p. 168). Bourdieu's relational model with its predominant focus on balancing the social and historical considerations provides the tools for researching the strategic value of the various paratextual positions that translators with their diverse habitus and species of capital can occupy.

The infusion of the social identity of paratext with historical analysis would bring to the fore the power structures at play and the heterogeneous nature of paratexts as exemplars of varying sociocultural and political conditions that exceed or possibly conflict with the translator's own interests and agendas. As such, the present study by no means aims to depict translators as "calculating persons acting only for their own interest", a notion entirely rejected by Bourdieu in his sociological view of agents (Buzelin, 2005, p. 200). The article offers a sketch of recent and past research on paratext, a detailed discussion of a particular case, and a conclusion that delineates the linguistic contours of the translation illusio, namely "the originating adherence to the literary game which grounds the belief in the importance or interest of literary fiction" (Bourdieu, 1995, p. 333; emphasis in original). I have found Bourdieu's sociology and Genette's paratextual theory to be a robust, interconnected conceptual framework, useful for researching and teaching the macro and micro features of paratext which exemplify the coaction of structure and agency. Before looking more closely at the case study, it would help in this context to first synthesize scholarly views that proliferate in the literature on paratext. Then, I will argue for a new reading of the paratextual apparatus of both translations, drawing on Genette's paratextual features (1997) and Bourdieu's sociology (1977).

\section{Paratext in Translation Studies and Beyond}

Paratextual framing seems to be deeply rooted in the history of translation as a profession. Commenting upon the 1740 edition of Droit de la nature et des gens (Law of Nature and People), Päivärinne (2008, p. 7) notes that "in the 18th century French translations of academic writings, translators often combined the role of translating and that of commentating the text". From the nineteenth century onward, multiple paratextual devices dominated the several English translations of the Arabian Nights by Lane (1841), Burton (1885), 
Haddawy (1990), and Lyons (2008). And indeed, the various translators used paratexts not only to critically engage with previous translations, but also as a tool for self-reflection on the text, the standing of translation, and the overall condition of their own discipline (Shamma, in press). Thus conceived, paratext enacts an ideological critique of the foreign text and earlier translations, and enables translators to question the conditions of their own work in relation to various developments, social and cultural, national and international. Additionally, paratextual material serves a wide range of extratextual functions that determine the production, circulation, and reception of texts.

Paratextual intervention affects the reception of literary works in multiple fashions, a view which finds expression in Alvstad's (2012) account of paratext as an influential means of promoting literary products. Alvstad (2012, p. 78) notes that "when publishers present their lists, books and authors on websites, advertisements, book covers, forewords, and so forth, these paratextual framings influence reception". Such frames, particularly prefaces, are instrumental to not only market a given translation, but also to highlight the translator's possessed capital. Investigating the reception of Nemirovsky's Suite Francaise in Britain, Kershaw (2010, p. 1) points out that "an analysis of the reception of the translated text in the target culture should pay attention to paratextual elements". The value of paratexts can be ascribed to the fact that they contribute to historically and culturally contextualizing translation vis-à-vis the source text (ST), thus lending the reader a hand in decoding its cultural significance and otherness. Echoing this view, Kovala (1996, p. 120) relates the importance of paratext to the assumption that "for translation the need for mediation is naturally much more urgent than in the case of an original literature, because the work is often far from its recipient historically and culturally". Moreover, paratextual material plays a pivotal role in the survival of translations across ages, a conviction supported by Newmark (1991, p. 41) who postulates that "a translated novel without a translator's preface ought to be a thing of the past". Of all the paratextual elements, preface seems to be the most influential site in which translators can engage in a direct dialogue with the critical establishment.

In prefaces, translators hedge their positions against potential criticism, fault the diction of previous translations, and disclose interpretative choices conditioned by existing linguistic norms and literary canons. Referring to this, Hartama-Heinonen (1995, p. 34) points out that prefaces are requisite to "forestall future criticism or to explain why the translator is not fully satisfied with his assignment". Viewed from this perspective, paratextual elements take on an added importance in the context of intercultural encounters, on the grounds that paratext, as Watts (2000, p. 32) observes, "evokes the work's difference while rendering that difference familiar or knowable". The literature presented thus far indicates that paratext makes more explicit the role of translation as a composite of overlapping linguistic and sociocultural determinants. The capacity to explore these determinants requires an interactive approach (both linguisticsociocultural and sociocultural-linguistic). To illustrate the modes of interaction between these domains, this paper develops a two-fold theoretical framework combining insights from Genette's paratextual theory (1997) and Bourdieu's sociology (1977).

\section{Mapping out the Paratextual Sites through Genette's Five Features}

Genette (1997) suggests five features that can be individually or collectively utilized in investigating the characteristics of paratext. These are "the spatial, temporal, substantial, pragmatic, and functional characteristics" (Genette, 1997, p. 4). The temporal situation of a paratext refers to the date of the text's appearance whereas the spatial representation is mapped onto two categories: a peritext (located within the text) or an epitext (related material located outside the text such as 'authorial' reviews) (Genette, 1997). For the benefit of this paper, the definition of 'spatial' extends to include the spatial conditions of the ST production.

The substantial status of a particular paratextual message could be "iconic (illustration), material (for example, everything that 
originates in the sometimes very significant typographical choices that go into the making of a book), or purely factual" (Genette, 1997, p. 7). As for the pragmatic aspect, it deals with "the nature of the sender and addressee, the sender's degree of authority and responsibility, [and] the illocutionary force of the sender's message" (Genette, 1997, p. 8). Lastly, the functions of paratexts include "designating or identifying; description of the work (content and genre); connotative value; [and] temptation" (Genette, 1997, p. 12). Guided by this model and Bourdieu's conceptual tools (1977), I will unpack the paratexts, with an eye on showing the extent to which paratexts have branded the reception of both translations. While it is possible, as we have seen, to theoretically conceptualize the features of paratexts from a linguistic standpoint, considering the structure-agency problematic takes us into the major issues of the sociological underpinnings of paratexts which will be dealt with in light of Bourdieu's theory of practice (1977).

\section{Bourdieu's Theory of Practice}

As a premise, the use of Bourdieu's theory of practice (1977) as a conceptual framework has increasingly gained wide currency in a range of research areas such as medicine, psychology, and education. The theory of practice can be viewed as an abstract, grand conceptual tool whose main pillars are field, habitus, and capital. Bourdieu (1990, p. 87) conceives of fields as "historically constituted areas of activity with their specific institutions and laws of functioning". In other words, social fields are spaces where agents and institutions are embedded and interact with each other in conformity with fields-specific rules. It is worth observing that Bourdieu does not blind the fact that fields are not completely autonomous, but rather a locus of competition and struggles among agents over relative positions and diverse forms of capital, namely economic, cultural, social, and symbolic capital.

Economic capital points to a person's revenues and financial resources; it can be institutionalized in the form of property rights (Bourdieu, 1986). Cultural capital exists in three non-financial forms: embodied (intellectual qualifications), objectivized (material objects such as books), and institutionalized capital (formalized academic qualifications such as certificates). Symbolic capital is the aggregate of all the preceding categories. That is, it exemplifies the resources possessed by agents by dint of prestige or recognition. The agents with their diverse species of capital act in accordance with the field doxa-namely, the confines of social mobility inside a given social field - and the laws of experience that organize practices within a specific field (nomos) (Bourdieu, 1977). By habitus, Bourdieu refers to a system of dispositions that produces "practices in accordance with the schemes engendered by history" (Bourdieu, 1977, p. 79).

The concept of habitus explains our tendency to act the same in diverse situations. It is habitus that constructs our understanding of the field's illusio, that is, "the value of the stakes of the game and the practical mastery of its rules" (Bourdieu \& Wacquant, 1992, p. 117). By way of illustration, the habitus "assures the collective belief in the social game (illusio) and that actors act in accordance with their position on the field (doxa), which depends on their relative amount and structure of economic, cultural, and social capital" (Walther, 2014, p. 12). In the case of my study, the laid-out conceptual framework will be utilized in investigating the social complexities surrounding the genesis of paratext in Bashir's earlier translations (e.g., Gibran, 1923). This includes throwing light on the interaction between the translators' agency and social structures in which they are embedded.

\section{The Genesis of Paratext in Bashir's Earlier Translations}

Considering the Archimandrite's social trajectory and the historical context that motivated the genesis of paratext in his earlier translations (e.g., Gibran, 1918, 1923), it should not be surprising that paratextual material played a minimal part in his translation Alihat Al-ard. With his symbolic capital and physical proximity to Gibran as his friend and translator, Bashir "took the lead in relocating Gibran's English writings to his native language readership" (Qubaisi, 2015, para. 10). Bashir's 
symbolic capital resides in the habitus of a metropolitan and was acquired through being an active member of his society; so much so that the late Fr. Alexander Schmemann once called him "the founding father of the American Church" (as cited in Samore, n.d, para. 1). Likewise, his symbolic capital as a translator can be attributed to "his ability to mimic Gibran's biblical language" (Qubaisi, 2015, para. 10). Suffice it to quote Gibran's words in reply to Mikhael Naimy when the latter sought his opinion about Bashir's translation, "let him write the way he thinks fit [...] However his translation might be, my spirit will be in it" (as cited in Qubaisi, 2015, para. 10). In fact, Bashir was highly visible as a translator in his society, partly because Gibran entrusted him with the Arabic translation of his main English works (Boosahda, 2003).

The quality label which states that this is 'the only translation approved by Gibran' adorns the covers of some of Bashir's translations such as The Forerunner and The Madman. Besides his social trajectory and substantial amount of capital, the explanation for the absence of paratexts in Alihat Al-ard is historically plausible, and much evidence supports it. Bashir did not feel called upon to justify the need for an inaugural translation of The Earth Gods, and the writer had long been the driving force behind the inclusion of paratexts into Bashir's earlier translations. Gibran seemed loath to let his translated works travel from the field of production to the field of reception without a paratextual carrier. In a letter addressed to Bashir before publishing the Arabic version of The Prophet, Gibran states:

As far as I am concerned, the most deserving of all people to write the introduction is you because he who spends days translating a book from one language to another is certainly the most knowledgeable of all people about the merits and shortcomings of that book. This is my opinion. However, I ask that you please do what you wish concerning the introduction and the excerpts from the American newspapers. (El-Hage, 2005, pp. 175-176)
This statement ostensibly indicates the extent to which Gibran was sensitive to the differing modes of reception in view of the doxic practices deeply rooted in target societies and of the unequal power relations among the various fields.

For Gibran, it is the task of the translator to evaluate the target sociocultural context, a view explicitly translated in vesting Bashir with the authority to include or exclude the drawings from the Arabic version of The Prophet, intended to be published in Egypt (El-Hage, 2005). Gibran made clear that he could not decide on whether or not the drawings should be incorporated in the target text (TT) because he does not "know anything about the Egyptian mentality", referring to the German and Norwegian translations that had come out without drawings (El-Hage, 2005, p, 177). Further evidence can be found in another letter to Bashir in which Gibran hailed the French translation of The Prophet as "a rare masterpiece", and pointed out that the ambassador of Mexico to Chile "had already translated the book into Spanish and that the book will be published shortly with a long introduction" (El-Hage, 2005, pp. 172- 173). Understanding Bashir's position toward paratexts is only possible in relation to this historical backdrop and his social position visà-vis the writer. Both were physically situated in the source society, with Gibran being more concerned about the nomos of each target society, which probably implies an intent on yielding both symbolic and economic capital among his native language readership.

Gibran as a binational writer was fully cognizant of the competition and mutual restraint among such fields as politics, literature, and religion within target contexts. The tension between fields in the social space places a moral duty on translators to act in conformity with their position on the field (doxa) and their inside knowledge of the checks and balances as well as power structures within target cultures, hence adapting their habitus in such a way that would tie in with the nomos and expectations of these contexts. Herein lies the power of paratext in facilitating intercultural encounters in milieus marked by different nomos and unbalanced power relations where, for example, the religious field might 
overpower the literary one or vice versa. Bourdieu goes much further than Gibran in writing prefaces to the translated versions of his books to throw light on the pitfalls of cultural exchanges. As Bourdieu (Bourdieu, 1999, p. 221) notes, "many misunderstandings in international communication are a result of the fact that texts do not bring their context with them".

The absence of paratext in Bashir's translation indicates a less acknowledgement of the stakes of the field and a less willingness to acquire the interests and investments embedded in the field. Thus, the illusio with its corresponding elements of motivation and interest become crucial, particularly where players enter the playing field from unequal positions of power in the form of varying types and volume of capital (Inghilleri, 2005, p. 136). Without the usual quality label, Alihat Al-ard was published a year after Gibran's demise. It only features a table of contents which is intended to help the reader navigate through the poem and the multiple chapters of The Forerunner. Bashir, it seems, was more concerned with vivifying Gibran's biblical language and thoughts than mediating the reception of the inaugural translation of The Earth Gods or illuminating the socio-historical context, as opposed to the translations which followed upon Bashir's.

In his retranslation (Arbab Al-ard - 'the lords of the earth'), Okasha was deeply sensitive to the complex conditions of reception and the demands of his hypothetical readership, infusing the translation with massive paratextual elements. His paratexts include a preface, illustrations with captions, critics' reviews, and a bibliography of his own translations and publications. The paratextual material makes up $55 \%$ of Okasha's fifth edition (Gibran, 2009), which is 53 pages in length. The preface warrants eight pages in its own right. More importantly, the first edition presents both English and Arabic in a parallel format, which adds another visibility dimension and turns translation into a teaching material. His translation has, thus, become a rich source of learning and comparative analysis for translation researchers and students. In what follows, I will look at the macro and micro features of the preface in light of Genette's features (1997) and Bourdieu's theory of practice (1977).

\section{Preface: Foregrounding the Illusio}

It is not hard to see that the preface, which constitutes almost $15 \%$ of the entire book, occupies a prominent position in the translation. Okasha with his symbolic capital attempted to orient the reader to his own hermeneutic paths and his own view of Gibran as well as The Earth Gods. Discussing the spatio-temporal aspects of the ST, Okasha indicates that the book was Gibran's last work and quotes the author's friend Barbara Young as saying that two thirds of the book were completed between 1914 and 1915 in New York (Gibran, 2009, p. 5). Young, notes the translator, encouraged Gibran to finish writing the book after he had put it aside for ten years. The translator then introduces the other narratives expounded by Gibran's friends, including Mikhael Naimy who believes that Gibran commenced writing this book only after completing Jesus the Son of Man. Therefore, Okasha adequately discusses the chronotope of the ST production, and provides his hypothetical readers with the germane historical and social context.

Indeed, many publishers and online book retailers quoted this socio-historical context to market not only Okasha's translation but also that of Bashir (see Amazon, Goodreads, Google books, Katara Novels, Abjad, and Albookar). Therefore, it can be posited here that thematizing the spatio-temporal dimensions in the preface contribute to drawing a dividing line between the ST as a socially situated activity and that of the TT. At several points, the pragmatic elements can be gauged from the translator's symbolic capital as a writer and translator which manifests itself in the influence he exercises, as a commentator and a critic, on readers and even on the writer by hinting that the ST seems to have been inspired by William Blake's Vala (Gibran, 2009). And moreover, he inscribes the preface with subtle allusions to his hypothetical target readership.

In the preface, the translator identifies his target audience indirectly by raising two questions toward the end of the introduction, wondering if Gibran intended this work to be a reference 
for Sufis (mystics) or it was meant to be an errant dreamer's ideas involving code-locked secrets (Gibran, 2009). This suggests that his hypothetical target audience are either Sufis or readers interested in mystery-loaded literature. Resultantly, Okasha would tinge his literary habitus with Islamic orientation to produce a hybrid language with the aim of attending to the habitus and social reality of his audience, intervening as an influential agent and conferring on the author and the ST a quantity of capital by submitting the poem "to the logic of a target literary field and its mechanisms of recognition" (Gouanvic, 2005, p. 162). In doing so, the translator foregrounds the illusio surrounding the production of the TT. Put succinctly, the translation came out at the Nasserist era (1950s and 1960s) in Egypt when literature was largely subject to the dictates of politics; this can be subsumed under the then nationalization of the cultural landscape (Gad, 2017).

The nationalization resulted in the incarceration of prominent literary figures such as Louis Awad, a mishap which Okasha describes as "a serious lesson that I learned five months after assuming the position of Minister of Culture: the top officials only believes in the policemen's reports" (as cited in Gad, 2017, para. 23). That Okasha targets Sufis can probably be understood in the context of the state's endeavours to tighten the grip of Sufism in its crackdown on the deeply rooted Islamic movements, particularly the Muslim Brotherhood, being perceived at the time as a serious menace (Anan, 2017). The sociopolitical conditions probably pushed the translator outside his literary habitus to meet the demands of illusio - the underlying belief and interest in the game's sociopolitical stakes. The macro illusio manifests itself in the micro illocutionary force of the preface.

Indicative of the illocutionary force are the copious details about the target readership and the theme of power and conflict among the three gods. The references to the schema of power assert the translator's literary illusio. Okasha holds in the preface that the book is steeped in gloominess and death meditation, referring to the powers of Nature and the three gods as epitomes of our souls. In this way, the translator draws the reader's attention to his own reading of the theme of power which governs most of Gibran's works (AlbouOmrani, 2015). The schema of power cannot be understood independent of Gibran's social trajectory and the sociopolitical conditions which determined the production of the TT. His heterogeneous mysticism emerged from a full immersion into diverse philosophical schools pioneered by thinkers such as Nietzsche, Blake, Rousseu, and Renan (Günday, Kavak, \& Şahin, 2015). Therefore, it could be argued that the translator reinvents the Gibranian schema of power, the illusio of the ST, to reproduce a similar rebellion against the mainstream religious groups. Later in his life, Gibran became overly inspired by Nietzsche and his superman-based insights, revolting against the doxic practices of religious authorities. The following statement summarizes the differences between Gibran and Nietzsche:

Gibran found in Nietzsche an ally who, like him, raged against the corruption of institutionalized religion and the hypocritical control it exercised over society. However, unlike Nietzsche, who totally rejected religion, Gibran's natural impulse was to attempt to reform it. (Bushrui \& Jenkins, 2008, p. 95)

The general point to be made is that explicating Gibran's schema of power ties in with the political and social climate of the Nasserite era which pushed against Salafism and Muslim Brotherhood and in favor of Sufism. Of all Gibran's English writings, Okasha selectively translated five mystically loaded works: The Prophet, The Garden of The Prophet, The Earth Gods, Jesus The Son of Man, and Sand and Foam. Besides the pragmatic features, Genette's four functions of paratexts (1997) find expression in Okasha's detailed preface, namely, identification, description of the work, connotative value, and temptation (Gibran, 2009 , p. 5-12). Together with describing the book genre as epic, the preface explores in detail the journey of the three gods and decodes the thrust of the poem that an average reader might grapple with. Thus conceived, Okasha dictates his reading of the ST. And herein lies the function of the connotative value assigned to the preface. In doing so, Okasha "primed the reader, who will set about the first chapter with a set of expectations controlled by or at least 
guided by" the explanation and justifications put forward in the preface (Pellatt, 2013, p. 3).

Another aspect of the preface's connotative value can be glimpsed in his explanation of the meaning of love by reminding the reader that it does not mean 'agape' (an interpretation embraced by Bashir) but human love between men and women, quoting Gibran's words at the very end of the poem (Gibran, 2009, p. 7). This demonstrates that Okasha attempted a departure from the Archimandrite's version whose hallmark is the use of the word 'الـــــــــ' (almahabah - 'agape'). Additionally, it is contended that the preface entices the reader by expanding on Gibran's suffering while producing this work; for example, how, just after publishing the book, the author received a first edition which was black in color. He, then, sat turning the pages of the book while muttering some of the stanzas to himself. This took place just a couple of weeks prior to his demise. Seen from this perspective, the preface serves a tempting function. Despite the thorough nature of the preface, the translator does not explicitly highlight the motivations behind his retranslation nor does he discuss previous translations.

The preface lacks an open dialogue with previous translations, which is a common feature of prefaces to retranslations because the values they create are determined "not only by the domestic values which the translator inscribes in the ST, but also by the values inscribed in a previous version" (Venuti, 2003, p. 25). Inexplicably, the translator states at the very end of the preface that the book entails a plethora of beauty that "stimulated us to add it to the Arabic literary library", hoping that with this "we would have done justice to the prominent Arab poet Gibran Khalil Gibran" (Gibran, 2009, p. 12). This statement raises many questions: was Bashir's translation considered to be inadequate? Or was it a matter of power relations whereby Okasha with his overwhelming symbolic capital and political power was in a position to retranslate without justifying the need for a new translation? The answer might be that his multiple paratextual devices imply an attempt to situate his translation in relation to previous ones.
Overall, the preface enabled the translator to build the socio-historical context of the ST production, justify his translational choices, explain the gist of the poem, identify his hypothetical target audience, and provide further insights into the suffering which the writer had experienced right up to the point of publication. The preface offers both intratextual and extra-textual information intended to influence the readers by triggering certain emotions and creating an intriguing, favorable milieu for a new reception, indirectly drawing a line between his interpretation and that of earlier translators. To support the added value of the retranslation, Okasha employs another influential paratextual device - critics' reviews (Gibran, 2009, p. 46).

\section{Critics' Reviews and Social Capital Dynamics}

Arbab Al-ard features four reviews by reputable literary authorities in Egypt during the sixties: Saleh Gawdat, Youssef Idris, Ahmed Hamroush, and Al-'Awadi al-Wakeel. Such favorable comments function as consecrating frames of Okasha's translation (Gibran, 2009, pp. 46-47). Put differently, the translator benefits from his social capital and the symbolic capital invested in those critics who wrote a canonical genre (e.g., poetry and fiction) in the field. The reviews introduce him as both a credible translator and an author with a unique, elegant style which enabled him to "bring Gibran's treasures home" (as cited in Gibran, 2009, p. 46). By way of explanation, the reviews establish the translator's 'embodied cultural capital" exemplified by his translation style, poetic knowledge, and unique lexis (Bourdieu, 1986, p. 244). The critics further praise his linguistic choices and "faithfulness to the ST", among others (as cited in Gibran, 2009, p. 46). Therefore, it is understandable why such favorable comments "have ideological significance in guiding and, to a degree, governing the readers' reading experience" (Pingping, 2013, p. 37). These authoritative reviews would likely affect the reader's perception and evaluation of the entire translation. As Bourdieu (1992, p. 239) observes, "the authorized point of view may come from a great critic or prestigious prefacewriter or established author". It follows that 
these reviews would exert symbolic effect on readers.

More crucially, the strategic positioning of such reviews as an epilogue within the back matter and immediately before the bibliography section suggests that they are meant to credit the translator and assert his overall contribution to the field. Therefore, the critics' reviews bring to the fore his social capital and spotlight his embodied cultural capital. From this perspective, the reviews carry out a tempting function, while at the same time having a material value ensuing from expanding the poem and granting it the features of a book. The last peritextual site is the list of the translator's publications which joins forces with the critics' reviews in further crediting the translator and showcasing more forms of his cultural capital.

\section{Bibliographies: The Translator's Authorship and Cultural Capital}

Rather than reproducing an illusionistic effect of authorial presence, the bibliography displays the translator's "objectivized and institutionalized cultural capital" in a space usually reserved for authors or publishers (Bourdieu, 1986, p. 243). The bibliographical note lists 20 translations, 25 Arabic literary studies, 14 lectures, three English books, two research projects, and one forthcoming encyclopaedia. The diversification of the items listed adds a symbolic value to a space driven by economics. His symbolic capital is manifested in a superior credibility; he translated and authored a canonical genre (fiction) judged as first rate literature, along with acquiring positive reception from those who had the power to say what counts as literature. Therefore, "authorized agents impose a public di-vision in the form of titles, academic degrees or professional qualifications" (Hanna, 2005, p. 175). The exhibition of the translator's academic contributions and titles contributes to cementing "the professionally authoritative image" of all his translations (Kung, 2013, p. 63). In addition, listing his professional works functions "as an endorsement to offer some guarantee to readers about the professional authority of the translation" (Kung, 2013, p. 63). This bibliography is of particular interest, not only as a means of promoting the translator's cultural capital, but also as a marketing tool designed to invite the reader to consider the acquisition of the translator's other works. Therefore, bibliographies of such type serve a tempting function. In bibliographies, the reader is invited to construct an image of the translator as an author and as an active social agent, which in turn extends a strong bridge of trust between the reader and translator.

\section{Concluding Remarks}

As noted above, paratext has been extensively researched from linguistic and sociocultural perspectives, with scholars mostly discussing the agency of translators as cultural mediators and asserting an individualistic concept of subjectivity. To bridge the agency-structure divide, this research attempted a bidirectional analysis of The Earth Gods, resulting in a mutually determining relationship, which demonstrates the extent to which the language of sociology facilitates access to the discourse of paratext. Similarly, complex power structures can be glimpsed through tracing certain peculiarities in the diction of the paratext. Additionally, the paper uncovered diverse paratextual strategies whereby Okasha has challenged the second-order status of translation by simply accentuating its translatedness. And yet, the multiple paratexts set Okasha up as an author with his own copyrights, introduction, illustrations, critics' reviews, and bibliography, thereby endorsing the translation. These paratextual positions could contribute to a change in the economics of translation. The various forms of the translator's capital distributed throughout the paratextual apparatus attest to the role of external patrons such as publishers and critics in delegating various forms of capital to the translator. That being the case, the bidirectional investigation of structural and agential accounts in paratext can be useful and valuable for researchers and practitioners asking how to endow translation with visibility and distinction, how to forestall its aging, or how to resist its cultural marginality and economic exploitation. In other words, "there is a need to emerge from the corporate translator bubble because translation-what it demands, implies, its effects, challenges, etc.- touches more than just translators (Gambier, 2014, p. 11) 
Of particular note is Bourdieu's concept of illusio, a signifier of the belief that the game we collectively play is worth playing. It is the preface space that fronts the illusio, namely the stakes and interests which motivate translators and their patrons to actively enter the playing field. The illusio evolves in tandem with the sociocultural and political dynamics lurking in the fields with their embedded power relations. Decoding the illusio was only possible in relation to the social trajectories of both the writer and translators. It is thereby argued that the illusio grants (re)translations a form of distinction. The identification of target audience and the provision of an interpretation are the most overt methods of devising illusio, rendering it all the more realistic. Resultantly, it would be profitable to conceive of prefaces as sites of illusio. Put differently, preface is an epistemological account whereby the translator answers the why, what, and who questions collectively or individually. Much of the preface's data can be classified as epistemological, namely the way the translator's mind applies its concepts to the social reality. In conclusion, future studies could thoroughly examine the impact of paratextual strategies on the reception of translation. There remain several unanswered questions as to how far a mapping of the illusio might help translators produce a consistent, distinctive discourse.

\section{References}

Albou-Omrani, M. (2017). ālbinīä̈, ālma nỳ, ālīdīūlūğiā: ālbunỳ ālṣuggrỳ wālkubrỳ wāl 'līā fì ādab Gibran Khalil Gibran [Structure, meaning, ideology: Microstructures, macrostructures, and superstructures in the literature of Gibran Khalil Gibran]. Al-Khitāab, 20, 41-62.

Alvstad, C. (2012). The strategic moves of paratexts: World literature through Swedish eyes. Translation Studies, 5(1), 78-94.

Anan, E. (2017, May 11). Kaīfa Tahūalat ālsūfït fì Maṣ 'âl 'ādaü b' aīdī âl' nẓimaẗ alhākimë [How did Sufism in Egypt turn into a tool in the hands of regimes?]. Noon Post. Retrieved from https://www.noonpost. org/content/17946.

Arabian Nights. (1841). The thousand and one nights, commonly called, in England, the
Arabian nights' entertainments. A new translation from the Arabic, with copious notes (Vols. 1-3., E. Lane, Trans.). London: C. Knight \& CO.

Arabian Nights. (1885). A plain and literal translation of the Arabian nights' entertainments, now entitled the book of the thousand nights and a night (Vols. 110., R. Burton, Trans.). Benares: The Kama Shastra Society.

Arabian Nights. (1990). The Arabian nights, based on the text edited by Muhsin Mahdi (H. Haddawy, Trans.). New York: W. W. Norton \& Company.

Arabian Nigts. (2008). The Arabian nights: Tales of 1001 nights (Vol. 1., M. Lyons, Trans.). London: Penguin Classics.

Boosahda, E. (2003). Arab-American faces and voices: The origins of an immigrant community. Austin: University of Texas Press.

Bourdieu, P. (1977). Outline of a theory of practice (R. Nice, Trans.). Cambridge: Cambridge University Press (original work published 1972).

Bourdieu, P. (1986). The forms of capital. In G. Richardson (Ed.), Handbook of theory and research for the sociology of education (pp. 241-58). New York: Greenwood Press.

Bourdieu, P. (1990). In other words (M. Adamson, Trans.). Cambridge: Polity Press.

Bourdieu, P. (1992). Language and symbolic power (G. Raymond \& M. Adamson, Trans.). Cambridge: Polity Press.

Bourdieu, P. (1993). Sociology in question (R. Nice, Trans.). London: Sage Publications.

Bourdieu, P. (1995). The rules of art, genesis and structure of the literary field (S. Emanuel, Trans.). Stanford: Stanford University Press.

Bourdieu, P. (1999). The social conditions of the international circulation of ideas. In R. Shusterman (Ed.), Bourdieu: A critical reader (pp. 220-228). Oxford: Blackwell.

Bourdieu, P., \& Wacquant, L. J. (1992). An invitation to reflexive sociology. Cambridge: Polity Press.

Bushrui, S., \& Jenkins, J. (2008). Kahlil Gibran, man and poet: A new biography. Oxford: Oneworld.

Buzelin, H. (2005). Unexpected allies: How Latour's network theory could 
complement Bourdieusian analyses in translation studies. The Translator, 11(2), 193-218.

Cicero, M. T. (1949). De inventione, de optimo genere oratorum, topica $(\mathrm{H}$. Hubbell, Trans.). Cambridge: Harvard University Press.

El-Hage, G. (2005). Gibran's unpublished letters to Archbishop Antonious Bashir. Journal of Arabic Literature, 36(2), 172182.

Gad, M. (2017, July 26). Tāmīm āltakafä̈ fī 'ahd 'abdul Nasser ... hal istafada $\mathrm{al}^{-}$bda' min AlmaŠrū' Alkaūmī kā̄fa tahūlat

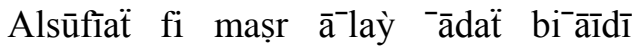
āl'nz̧imä̈ ālḥakimä̈ [The nationalization of culture at the time of Abdul Nasser... Did creativity benefit from the national project?]. Alahram Gate. Retrieved from http://gate.ahram.org.eg/News/1556216. aspX

Gambier, Y. (2014). Changing landscape in translation. International Journal of Society, Culture \& Language, 2(2), 112.

Genette, G. (1997). Paratexts: Thresholds of interpretation (J. Lewin, Trans.). New York: Cambridge University Press.

Gibran, K. (1918). The madman (A. Bashir, Trans.). Cairo: Elias' Modern Press.

Gibran, K. (1923). The prophet (A. Bashir, Trans.). Cairo: Elias' Modern Press.

Gibran, K. (1932). The earth gods and the forerunner (A. Bashir, Trans.). Beirut: Al-maktabat Al-Thaqafiat.

Gibran, K. (1965). The earth gods $\left(1^{\text {st }}\right.$ ed., T. Okasha, Trans.). Cairo: Dar Al-Marref.

Gibran, K. (2009). The earth gods $\left(5^{\text {th }}\right.$ ed., T.

Okasha, Trans.). Cairo: Dar Al-Shorouk.

Gouanvic, J. (2005). A Bourdieusian theory of translation, or the coincidence of practical instances: Field, 'habitus', capital and 'illusio'. The Translator, 11(2), 147-166.

Günday, H., Kavak, F., \& Şahin, S. (2015). Literary influences of Gibran Khalil Gibran. International Journal of Business and Social Science, 6(3), 148154.

Hanna, S. (2005). Hamlet lives happily ever after in Arabic. The Translator, 11(2), 167-192.

Hartama-Heinonen, R. (1995). Translators' prefaces - A key to the translation? Folia Translatologica, 4, 33-42.
Inghilleri, M. (2005). The sociology of Bourdieu and the construction of the 'object' in translation and interpreting studies. The Translator, 11(2), 125-145.

Kershaw, A. (2010). Sociology of literature, sociology of translation: The reception of Irène Némirovsky's Suite Française in France and Britain. Translation Studies, $3(1), 1-16$.

Kovala, U. (1996). Translations, paratextual mediation, and ideological closure. Target, 8(1), 119-147.

Kung, S. (2013). Paratext, an alternative in boundary crossing: A complementary approach to translation analysis. In V. Pellat (Ed.), Text, extratext, metatext and paratext in translation (pp. 49-68). Newcastle: Cambridge Scholars Publishing.

Newmark, P. (1991). About translation. Clevedon: Multilingual Matters.

Päivärinne, M. (2008). Enlightened translations. Knowledge mediation and Jean Barbeyrac. In D. De Crom (Ed.), Translation and the (trans)formation of identities. Selected Papers of the CETRA Research Seminar in Translation Studies (pp. 1-14). Retrieved from https://www. arts.kuleuven.be/cetra/papers/files/paiva rinne.pdf.

Pellatt, V. (2013). Introduction. In V. Pellat (Ed.), Text, extratext, metatext and paratext in translation, (pp. 1-8). Newcastle: Cambridge Scholars Publishing.

Pingping, H. (2013). Paratexts in the English translations of the selected works of Mao Tse-tung. In V. Pellat (Ed.), Text, extratext, metatext and paratext in translation (pp. 33-46). Newcastle, Cambridge Scholars Publishing.

Qubaisi, R. (2015, April 20). Gibran Khalil Gibran li nadīm Naīmah: Yakfī âl'abat biā'ḥlāmihi wasuțūihi [Gibran Khalil Gibran by Nadim Naimi: Enough tampering with his dreams and lines]. An-Nahar. Retrieved from https:// newspaper.annahar.com/article/230414.

Samore, P. (n.d). Remembering metropolitan Anthony Bashir on the 50th anniversary of his repose. Antiochian Orthodox Christian Archdiocese of North America. Retrieved from http://ww1.antiochian. org/remembering-metropolitan-antonybashir-50th-anniversary-his-repose. 
Shamma, T. (in press). The Arabian nights after orientalism: Paratextual sites of reflection and dialogue. In S. Bahadir \& D. Dizdar (Eds.), Reflexive translation studies.

Venuti, L. (2003). Retranslations: The creation of value. Bucknell Review, 47(1), 25-38.

Walther, M. (2014). Bourdieu's theory of practice as theoretical framework. In M.
Walther (Ed.), Repatriation to France and Germany (pp. 7-23). Wiesbaden: Springer Fachmedien Wiesbaden.

Watts, R. (2000). Translating culture: Reading the paratexts to Aimé Césaire's Cahier d'un retour au pays natal. TTR: Traduction, Terminologie, Rédaction, 13(2), 29-45. 